\title{
The structure and evolution of eye banking: a review on eye banks' historical, present, and future contribution to corneal transplantation
}

This article was published in the following Dove Press journal:

Journal of Biorepository Science for Applied Medicine

6 June 2017

Number of times this article has been viewed

\author{
Nathan G Lambert \\ Winston D Chamberlain \\ Department of Ophthalmology, \\ Casey Eye Institute, Oregon Health \& \\ Science University, Portland, OR USA
}

\begin{abstract}
The purpose of this review is to describe the increasing roles and responsibilities of eye banking with focus on its roles in the US historically, currently, and in the future. Since the establishment of the first eye bank by Townley Paton in 1944, eye banks have been responsible for both the safety and quality of corneal graft procurement, preparation, and distribution. Over time, eye banks have played an increasing role in the evolving world of corneal transplantation. Eye banks have repeatedly risen to new challenges regarding disease transmission, preparation of partial-thickness graft preparation, use of novel technology, and adjustment to meet constant increasing legislation and regulation. As the future will likely bring new opportunities as well as challenges, eye banks need to continually adapt to future technical and regulatory obstacles, ensuring that the future of corneal transplantation continues to be increasingly safe and successful. Keywords: eye bank, corneal transplant, DMEK, DSAEK, femtosecond laser
\end{abstract}

\section{Introduction}

It is estimated that 285 million people worldwide are visually impaired, of whom 39 million are blind. ${ }^{1}$ Corneal opacities and trachoma alone are estimated to account for $4 \%$ and $3 \%$ of world blindness, respectively, ranking corneal blindness behind only cataract $(51 \%)$ and glaucoma $(8 \%){ }^{1}$

Nearly 185,000 corneal transplants are performed each year in over 115 different countries, ${ }^{2}$ with nearly 80,000 performed in the US alone. ${ }^{3}$ Of the corneal grafts used worldwide, $87 \%$ are procured from donors within the same country, while 27 countries ( $1.2 \%$ of corneal transplants) rely solely on imported corneas to supply their need for corneal allografts. ${ }^{2}$ The US and Sri Lanka procure the most donated corneas per capita, at rates of 3.7 and 1.5 corneas, respectively, per 10,000 people, accounting for $94 \%$ of all exported corneas worldwide. ${ }^{2}$ Limited access to viable graft tissue remains a challenge in many parts of the world, leaving over half of the world's population without access to corneal transplantation services. ${ }^{2}$

Eye banks are institutions responsible for collecting, processing, and distributing donated ocular tissue for transplantation, helping to mitigate this disparity between corneal tissue supply and demand. Due to eye banking involvement and evolution over the past eight decades, waiting lists no longer exist in the US.

As a result of eye banking, over a million people have received successful corneal transplants in the US alone..$^{3-5}$ However, due to infectious and transmissible diseases, increased regulation, and new technology and techniques to further refine and redefine corneal transplantation, eye banks have and need to continue to rise to the challenge
Correspondence: Winston D Chamberlain

Department of Ophthalmology, Casey Eye Institute, 3375 SW Terwilliger Boulevard, Portland, OR 97239, USA

Tel +l 5034947674

Fax + I 5034943929

Email chamberw@ohsu.edu 
of providing safe, high-quality, and timely tissue for corneal transplantation. The purpose of this review is to describe the increasing roles and responsibilities of eye banking (with a focus on the US) throughout recent history, currently, and in the future.

\section{History of eye banking}

The first successful corneal transplant was performed in 1905 by an Austrian ophthalmologist Eduard Zirm. ${ }^{6}$ A 45-yearold farmer named Alois Glogar suffered lime burns to both corneas leaving him blind with bilateral, white corneal scars. A year after his injury, a 11-year-old boy named Karl Braur suffered a penetrating eye injury from a piece of iron. After collapse of the eye from multiple failed attempts to remove the intraocular foreign body, the boy's father granted permission for enucleation of the eye for transplant. ${ }^{7}$ A bilateral corneal transplant was performed on the farmer recipient using two grafts fashioned from the boy's single cornea. Several weeks after the operation, the right eye developed pain, which necessitated graft removal. However, even 6 weeks after initial transplant, the graft in the patient's left eye remained miraculously clear, marking the first successful corneal transplantation. ${ }^{7}$

Zirm's success was not replicated until 1914 when fellow-Austrian, Dr. Anton Elschnig, performed the second successful corneal transplant. ${ }^{8}$ These surgical advents were followed by the development of lamellar keratoplasty (selective removal and replacement of specific corneal layers, rather than the entire cornea) ${ }^{9}$ by a Russian Vladimir Filatov and the development of the double-bladed knife for square grafts by a Spaniard Ramon Castrovjiejo. ${ }^{10}$

In the early years of corneal transplantation, surgeons relied on enucleated eyes from living donors with posterior segment pathology or deceased patients in public hospitals. ${ }^{11}$ Procured tissue was time sensitive and required immediate transplantation. As such, each cornea surgery continued to be an emergent procedure, with those needing the transplantation subjected to stand-by status and non-scheduled surgeries dependent on available tissue. Unfortunately, in some areas of the world, corneas are still procured on limited basis and represent the only local source of tissue.

Understanding this need, Townley Paton established the first eye bank in 1944 called "Eye-Bank for Sight Restoration" in New York City, NY. This became the first tissue bank of any kind, precluding any other by half a decade. ${ }^{12,13}$

Following suit, more eye banks were established over the next several years until a committee of 27 ophthalmologists and 4 groups under the American Academy of
Ophthalmology and Otolaryngology formed the Committee on Eye Banks in 1955. In 1961, this committee gathered representatives from eye banks across the country to a meeting in which they unanimously voted to establish an association of eye banks. The association was officially established in October of 1955 as the Eye Bank Association of America (EBAA), ${ }^{10}$ becoming the world's first transplant association.

A system of eye banks was finally in place to collect and prepare corneal grafts; however, each eye bank continued to operate on its individual procedures and protocols. Years later in 1980, the EBAA created a set of medical standards for the handling of eye tissue and a training program for technicians ${ }^{10}$ — the first transplant organization to undertake this standardized approach to tissue handling.

Other developed countries in North America, Europe, and the Southwest Pacific rim have organizations similar to the EBAA where collaboration between corneal surgeons and eye bankers provides standards for safety, quality, and best practice. ${ }^{11,14-16}$ Eye banking continues to be the foundation of corneal transplantation across the globe.

\section{Eye banking in the US: present}

Eye banking in the US has grown steadily since its inception, especially in the past several decades. In the early 1990s, US eye banks provided 39,515 grafts for corneal transplantation, a number that doubled to nearly 80,000 by the year 2015 . In 2015, domestic US eye banks reported 130,987 total tissue recoveries from 66,526 donors. Nearly 79,304 tissues were distributed for keratoplasty, while 25,832 (34.6\%) of US intermediate-term preserved corneas (all refrigerated tissue stored in Optisol GS ${ }^{\mathrm{TM}}$ [Bausch \& Lomb, Rochester, NY, USA], Life $4^{\circ} \mathrm{C}^{\mathrm{TM}}$ [Numedis, Inc., Minneapolis, MN, USA], or Eusol CTM [Alchimia s.r.l, Ponte San Nicoló, Padova, Italy]) were used for full thickness and lamellar procedures or exported internationally (Table 1). ${ }^{3}$ Since 1961, US eye banks have provided tissue for over 1.5 million people worldwide. $^{3-5}$

The number of registered donors has also increased over time, with 2015 marking the second straight year that more corneas were recovered from individuals listed on their states' organ donor registry than through authorization by next of kin. ${ }^{3}$

Procured corneal tissue is used in a variety of different settings including transplantation, research, and teaching. Of all the transplants performed worldwide, $35 \%$ are performed in the US. ${ }^{2}$ A spectrum of surgical procedures utilizes different portions of corneal allografts, with each requiring unique and specific preparation by eye banks (Table 2). Eye banks 
Table I Use of donated tissue

\begin{tabular}{|c|c|c|c|c|c|}
\hline Distribution & 2015 & 2014 & 2013 & 2012 & 2011 \\
\hline Corneal grafts total & 79,304 & 76,431 & 72,736 & 68,681 & 67,590 \\
\hline Penetrating keratoplasty & 39,554 & 38,919 & 36,998 & 36,716 & 36,144 \\
\hline Anterior lamellar keratoplasty & 2,201 & 1,953 & 2,009 & $\mathrm{I}, 855$ & ।,778 \\
\hline Endothelial keratoplasty & 30,701 & 28,961 & 27,298 & 24,277 & 23,287 \\
\hline Keratolimbal allograft & 107 & 88 & 110 & 97 & 95 \\
\hline Keratoprosthesis (K-Pro) & 364 & 294 & 255 & 263 & 358 \\
\hline Glaucoma shunt patch or other non-keratoplasty use & 527 & 755 & 687 & 676 & 604 \\
\hline Other keratoplasty (experimental surgery) & 19 & 17 & 17 & 44 & 14 \\
\hline Unknown or unspecified & $\mathrm{I}, 142$ & 1,026 & 1,068 & $\mathrm{I}, 554$ & 2,223 \\
\hline Sclera & 3,225 & 3,345 & 3,693 & 3,497 & 5,507 \\
\hline Long-term preserved corneas & 11,672 & 7,223 & 4,840 & 5,095 & 4,409 \\
\hline Keratoplasty & 737 & 938 & 499 & 305 & 276 \\
\hline Glaucoma shunt patching & 10,843 & 6,212 & 4,040 & 4,435 & 3,802 \\
\hline Other surgical uses & 92 & 73 & 301 & 335 & 331 \\
\hline Research & 16,924 & 17,670 & 17,384 & 19,320 & 19,230 \\
\hline Training & 10,003 & 9,295 & 7,451 & 6,850 & 6,940 \\
\hline
\end{tabular}

Notes: The combined national and international use of corneal grafts released from eye banks within the US are described within this table. Adapted with permission from the 2015 Eye Banking Statistical Report by the Eye Bank Association of America. Copyright @ 2016 EBAA ${ }^{\oplus}$, Washington, DC; www.restoresight.org All Rights Reserved. ${ }^{3}$

Table 2 Corneal Transplantation Types

\begin{tabular}{|c|c|c|c|}
\hline Procedure & Abbreviation & Definition & Eye Bank Preparation \\
\hline Penetrating Keratoplasty & PK & $\begin{array}{l}\text { Full thickness corneal transplant, anchored } \\
\text { by radial sutures }\end{array}$ & $\begin{array}{l}\text { No pre-cutting of tissue is performed prior to transport } \\
\text { to surgeon }\end{array}$ \\
\hline $\begin{array}{l}\text { Femtosecond Laser- } \\
\text { Assisted Keratoplasty }\end{array}$ & FLAK & $\begin{array}{l}\text { Use of femtosecond laser (FSL) to perform } \\
\text { partial or full thickness corneal transplant }\end{array}$ & $\begin{array}{l}\text { Use of FSL to make PK graft with specialized edge shapes } \\
\text { for more tissue }\end{array}$ \\
\hline Endothelial Keratoplasty & EK & Partial-thickness corneal transplant of EDM & $\begin{array}{l}\text { Pre-cut corneal tissue via microkeratome to manually } \\
\text { dissect EDM from stroma }\end{array}$ \\
\hline $\begin{array}{l}\text { Oescemet Stripping } \\
\text { Endothelial Keratoplasty }\end{array}$ & DSEK & $\begin{array}{l}\text { Some residual stroma is left on EDM graft. } \\
\text { Dissection of recipient is performed } \\
\text { manually }\end{array}$ & $\begin{array}{l}\text { Use of trephine to cut through endothelium and } \\
\text { Descemet membrane into the posterior stroma. Tissue } \\
\text { transported as whole corneal scleral rim to surgeon for } \\
\text { manual dissection }\end{array}$ \\
\hline $\begin{array}{l}\text { Descemet Stripping } \\
\text { Automated Endothelial } \\
\text { Keratoplasty }\end{array}$ & DSAEK & $\begin{array}{l}\text { Some residual donor stroma is left on EDM } \\
\text { graft. Dissection of donor graft is } \\
\text { performed with microkeratome }\end{array}$ & $\begin{array}{l}\text { Use of microkeratome to dissect anterior cornea from } \\
\text { endothelium and Descemet membrane, leaving some } \\
\text { donor stroma }\end{array}$ \\
\hline $\begin{array}{l}\text { Pre-Descemet Endothelial } \\
\text { Keratoplasty }\end{array}$ & PDEK & $\begin{array}{l}\text { EDM graft contains pre-descemet's layer, } \\
\text { but not residual donor stromal. Dissection. } \\
\text { Dissection of donor graft is performed } \\
\text { manually }\end{array}$ & $\begin{array}{l}\text { Pneumodissection of EDM and overlying pre- descemet's } \\
\text { layer from overtying stroma, creating stroma-free donor } \\
\text { graft }\end{array}$ \\
\hline $\begin{array}{l}\text { Descemet Membrane } \\
\text { Endothelial Keratoplasty }\end{array}$ & DMEK & $\begin{array}{l}\text { EDM graft does not contain residual } \\
\text { donor stroma. Dissection of donor graft is } \\
\text { performed manually }\end{array}$ & $\begin{array}{l}\text { Peripheral EDM is scored manually. Using forceps or } \\
\text { pneumodissection, technician manually separates/peels } \\
\text { EDM from stroma. (Possible trephination and } \\
\text { pre-packaging of scroll in injector) }\end{array}$ \\
\hline $\begin{array}{l}\text { Descemet Membrane } \\
\text { Automated Endothelial } \\
\text { Keratoplasty }\end{array}$ & DMAEK & $\begin{array}{l}\text { EDM graft contains a residual peripheral } \\
\text { rim of donor stroma and barred descemet } \\
\text { membrane centrally. Dissection of donor } \\
\text { graft is performed with microkeratome }\end{array}$ & $\begin{array}{l}\text { Use of microkeratome to dissect anterior cornea from } \\
\text { posterior cornea and Descemet membrane. A big } \\
\text { bubble separates central endothelium, leaving behind a } \\
\text { peripheral stromal rim }\end{array}$ \\
\hline $\begin{array}{l}\text { Femtosecond Laser- } \\
\text { Assisted Descemet } \\
\text { Membrane Automated } \\
\text { Endothelial Keratoplasty }\end{array}$ & fDMAEK & $\begin{array}{l}\text { EDM graft contains a residual peripheral } \\
\text { rim of donor stroma and barred descemet } \\
\text { membrane centrally. Dissection of donor } \\
\text { graft is performed by femtosecond laser }\end{array}$ & $\begin{array}{l}\text { Use of femtosecond laser to assist in dissection of } \\
\text { Descemet membrane and endothelium from posterior } \\
\text { stroma centrally using a big bubble, leaving behind a } \\
\text { peripheral stromal rim }\end{array}$ \\
\hline $\begin{array}{l}\text { Hemi-Descemet Membrane } \\
\text { Endothelial Keratoplasty }\end{array}$ & Hemi-DMEK & $\begin{array}{l}\text { DMEK graft that is divided into two } \\
\text { semicircular grafts }\end{array}$ & $\begin{array}{l}\text { Full-thickness cut through corneal scleral rims to produce } \\
\text { semicircular graft, followed by standard DMEK preparation }\end{array}$ \\
\hline \multirow[t]{2}{*}{ Transplantation } & KLAL & $\begin{array}{l}\text { Transplantation of limbal stem cells into } \\
\text { patient v/ith ocular surface due to limbal stem }\end{array}$ & $\begin{array}{l}\text { Preservation of conjunctival peripheral skirt and larger } \\
\text { ncorneoscleral rim }\end{array}$ \\
\hline & & cell deficiency (LSCD) & during procurement \\
\hline
\end{tabular}

Note: The different types of corneal transplantation modalities as well as the roles that eye banks play in the preparation of each of the tissue grafts are described in this table. Abbreviation: EDM, endothelial-descemet membrane. 
continue to have increasing demands to safely and efficiently prepare tissues to meet requirements for particular surgical procedures, while adhering to increasing regulations and legislation.

\section{Eye bank structure}

Eye bank structure varies based upon the size, recovery volume, amount of processing, and connections with a larger organization (ie, university or hospital). Regardless of size, each eye bank must have staff to perform fundamental roles involved in patient eligibility and donation, tissue recovery, processing and distribution, as well as those to oversee the logistics, finance, and research operations of the eye bank. Eye banks are also responsible for tracking and reporting adverse events associated with distributed tissue. Each of these tasks is overseen by a director and led by a chief executive officer, who is guided by the medical director and board of directors (BOD). ${ }^{17}$ The following is a list of some of various eye bank support staff members (also see Figure 1):

- Eye bank director: responsible for day-to-day logistical activities of the eye bank.

- Medical director: usually a cornea fellowship-trained ophthalmologist that formulates, approves, and implements medical policies and procedures, trains technicians, and oversees quality metrics of prepared tissues.
- Donation/eligibility specialist: on-call telephone responder that accepts new referrals of recently deceased potential donors, contacts family members of deceased to obtain consent and perform initial screening surveys, and alerts recovery technicians and coordinates logistics of tissue procurement.

- Recovery technician: performs initial physical exam of deceased donor, draws blood samples, and performs surgical procurement of donor ocular tissue and returns the tissue to the eye bank.

- Processing technician: performs quality assurance tests on tissues including serological and microscopic testing on procured tissue, and cuts and dissects tissues as necessary to be used for various keratoplasties.

- Tissue distribution specialist: coordinates with local surgeons to ensure that required graft tissue is delivered to surgical center in time for scheduled corneal transplantation.

\section{EBAA}

\section{Organization and function}

Most eye banks operate under the administrative umbrella of the EBAA, which oversees the procedural, safety, and administrative and educational processes of its affiliated eye banks. The EBAA is based out of Washington, DC, and led

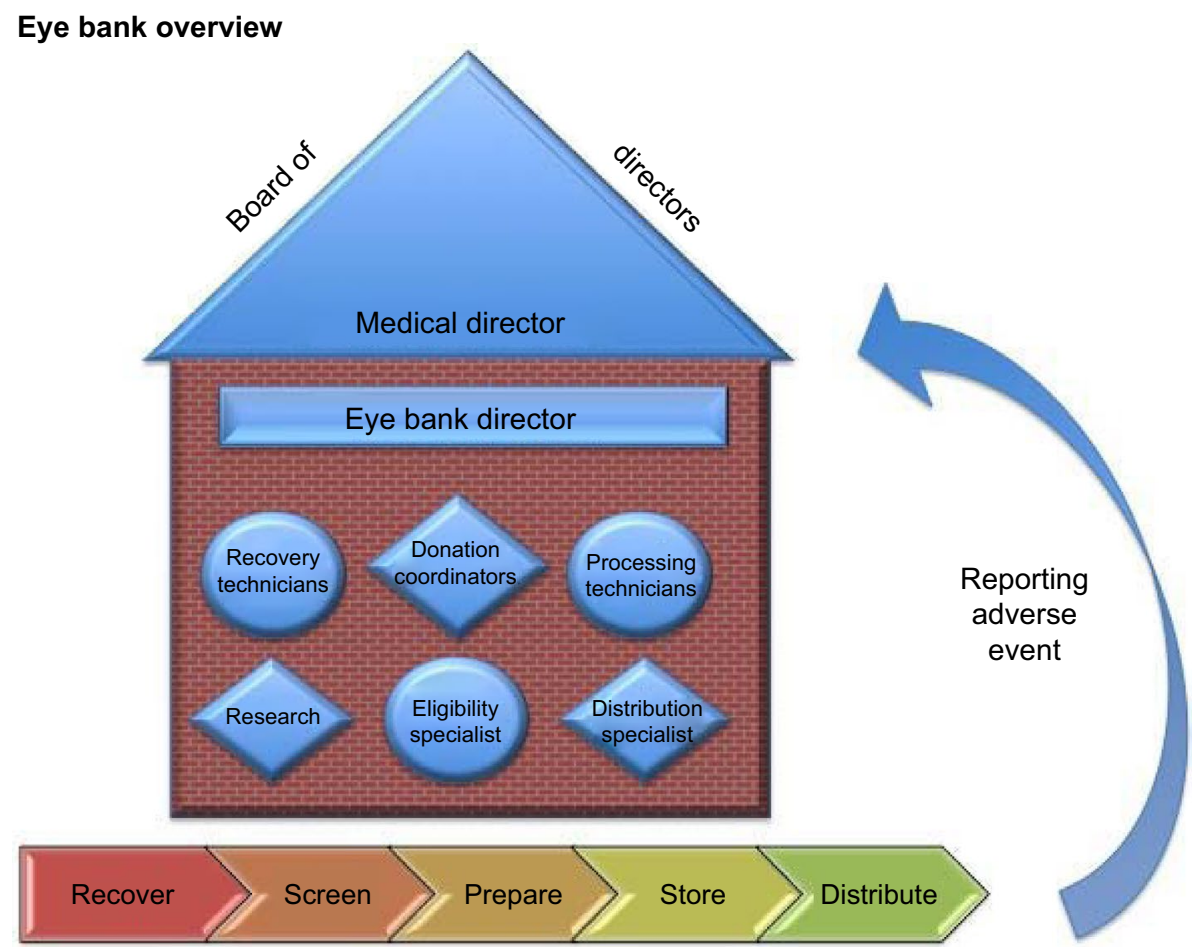

Figure I Eye bank overview.

Note: Displayed are the various members of an eye bank organization as well as the process of eye tissue recovery, screening, preparation, storage, distribution, and reporting adverse events. 


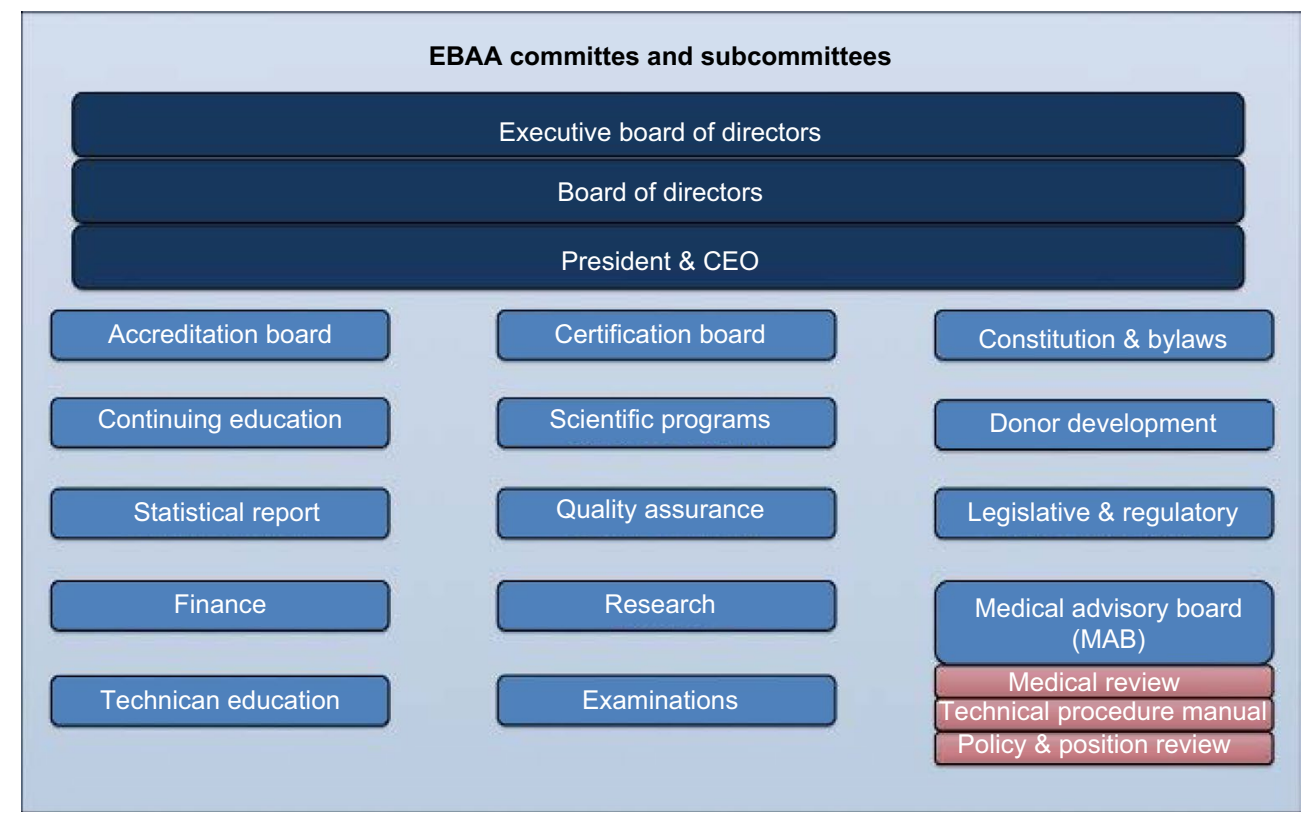

Figure 2 EBAA committees.

Note: Depicted are the various committees and subcommittees overseen by the EBAA leadership.

Abbreviation: EBAA, Eye Bank Association of America.

by a BOD consisting of ophthalmologists and eye bankers from across the country. This board oversees various committees including accreditation, education, donor development, finance, global outreach, legislation and regulation, quality assurance, research, technician education, medical advisory of best practices (Figure 2). Within this board lies the overseeing executive committee. Each associated eye bank provides voting representatives to the EBAA House of Delegates (HOD), a governing body that works under the direction of the BOD to address current issues facing eye banking. HOD representatives are selected from eye bank directors across the country (Figure 3 ).

The EBAA Accreditation Board, established in 1980, conducts inspections of member eye banks on a regular three-year cycle or more often, as necessary. Eye banks accredited by the EBAA follow the EBAA medical standards, and employ EBAA procedures, which closely parallel and often exceed those of the US Food and Drug Administration's (US FDA) Good Tissue Practice regulations.

As of 2015, the EBAA consisted of 71 domestic and 10 international member eye banks. Through its network of banks, the EBAA champions the restoration of sight through core services to its members by advancing donation, transplantation and research, and providing tens of thousands of patients with the gift of sight annually. ${ }^{3}$

\section{Medical standards}

The EBAA's medical standards define the minimum standards of practice for eye bank functions, and assure quality, proficiency, and ethics in dealing with ocular tissue for transplantation. ${ }^{17}$ These standards and procedures have been used as a model for adaptation by other organizations in the US and other countries. They are reviewed and revised twice a year by a board of renowned corneal surgeons and certified technicians with expertise and extensive experience in eye banking. The recommendations of the EBAA are formally considered by the American Academy of Ophthalmology (AAO), which has endorsed them each year since 1981. ${ }^{17}$ The EBAA standards represent "standard of care" practices in US eye banking and are based on science specific to ocular tissue. The MAB is responsible for promulgating EBAA medical standards and a FDA liaison often sits on the board. ${ }^{18}$

\section{Regulation}

EBAA practices are overseen by both the AAO and FDA. Although eye banking has led the field of tissue banking in standardization and safety, increased federal regulation over the years has dictated changes in policy and procedure of eye banking practices.

The FDA passed multiple legislative acts in the late 1980s and 1990 s, increasing regulations on organ and tissue donation. ${ }^{5}$ Some of these regulations mandated screening donors for Creutzfeldt-Jakob disease (CJD) and serologic testing for human immunodeficiency virus (HIV), hepatitis B virus (HBV), hepatitis $\mathrm{C}$ virus (HCV), ${ }^{19}$ and syphilis. Later, the FDA implemented or proposed other rules dictating reimbursement to eye banks for tissue processing,${ }^{20}$ protocols for notifying eye banks of a death, ${ }^{5}$ and requirement of facility 


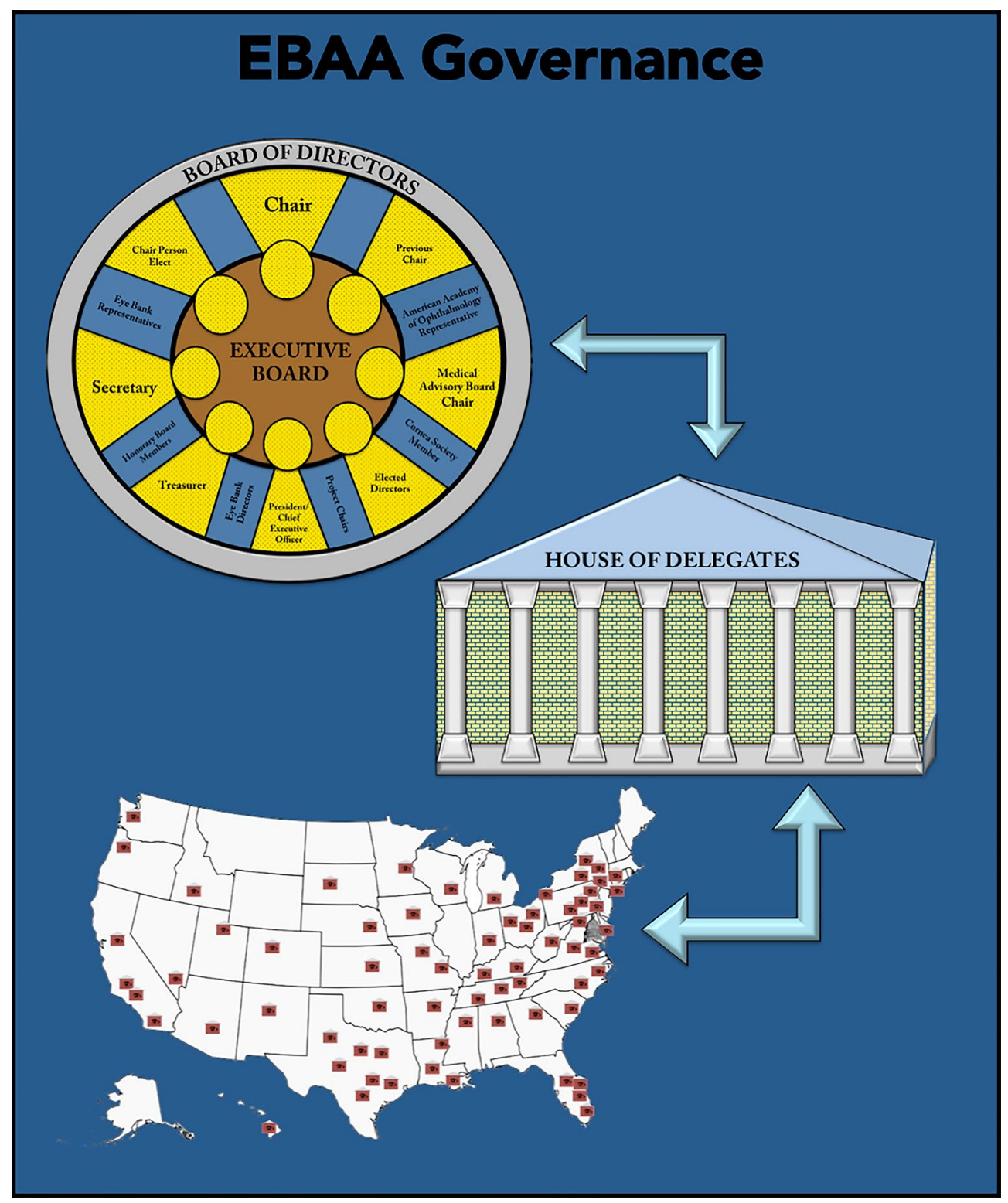

Figure 3 EBAA governance.

Notes: Shown are the relationships between the BOD, HOD, and eye banks across the country. The BOD comprises the current, previous, and incoming chair, a medical advisory board (MAB) chair, and various other members. Members of the executive committee of the board are noted in yellow. Current issues facing eye banking are discussed in the BOD and HOD. The map in this figure depicts EBAA-affiliated eye banks across the United States.

Abbreviations: EBAA, Eye Bank Association of America; BOD, board of directors; HOD, House of Delegates.

and laboratory inspections with proposed stipulations for noncompliance. ${ }^{5}$ In 2013, the FDA drafted legislation in that proposed mandatory nucleic acid testing for West Nile virus (WNV), ${ }^{21}$ despite the absence of any prior documented transmission of WNV via corneal transplantation. ${ }^{22,23}$ As such, the EBAA drafted a response in early 2014 specifying objections to the proposed testing. ${ }^{23}$

In an article written by former EBAA Chairman (19982000) Dr Wing Chu, the "EBAA proposed that the FDA not subject human eye tissue to new regulations until a public health threat was demonstrated" and "reiterated [to the FDA], its stance that the American corneal supply was safe, no public health threat existed, current regulations provided sufficient oversight, and that the FDA economic impact estimates [of its regulations] were understated".5

In his 1998 report published in Cornea, David Glasser warned that "every new test has a cost associated with it, not only in dollars, but in false positives and tissue wasted". ${ }^{24}$ He further recommended that the EBAA continues to advise FDA policy makers that regulations on organs and tissue donation must be based on scientific evidence and a clear understanding of both the benefits and risks. ${ }^{24}$

Effective screening remains imperative for safe use of corneal allografts, and regulations are likely to tighten rather 
Table 3 Tissue screening

\begin{tabular}{ll}
\hline Diseases or conditions that disqualify donor tissue & Donor behaviors that disqualify donor tissue \\
\hline Congenital rubella & Men who have had sex with another man in past 5 years \\
Active viral encephalitis or progressive encephalopathy & IV drug use \\
Active bacterial or viral meningitis & Known hemophiliac who has received clotting factors in past 5 years \\
Acitve bacterial or fungal endocarditis & Engaged in sex for exchange for money or drugs \\
Suspected rabies & Exposed to HIV, HBV, HCV \\
Retinoblastoma & Children born to mothers with HIV \\
Malignant tumors of anterior ocular segment & Juvenile detention, lockup, jail or prison for $>72$ hours in past I2 months \\
Adenocarcinoma in eye of primary or metastatic origin & Lived with person with HCV or HBV \\
Sepsis & Smallpox vaccination in past 8 weeks \\
Active disseminated lymphoma or leukemia & Residence for 3+ months cumulatively in United Kingdom \\
Viral hepatitis & Residence 5+ years cumulatively in Europe \\
History of Ebola & Received blood transfusion in United Kingdom or France between \\
& I980-present \\
Parkinson disease, Amyotrophic lateral sclerosis, Multiple sclerosis, and & Xenotransplantation product recipients or intimate contact of \\
Alzheimer disease & xenotransplantation product recipient \\
Active ocular or intraocular inflammation: conjunctivitis, keratitis, & Undergone tatooing, ear or body piercing in past I2 months in which sterile \\
scleritis, iritis, uveitis, vitreitis, choroiditis, retinitis & procedures were not used \\
Syphilis & Had or been treated for syphilis in last I2 months \\
Creutzfeldt Jakob Disease (CjD) & History or physical evidence of risky sexual behavior \\
History of Zika virus within 6 months prior to death & \\
\hline Nis
\end{tabular}

Note: This is not a comprehensive list of disqualifying conditions or behaviors. This table describes various conditions that may be discovered on history or physical examination of donors that would deem the donated ocular tissue ineligible for transplantation. The donor's ocular tissues are then sterilely prepped and recovered by technicians. Procurement procedures vary depending on intended use of the graft.

than loosen in the future. With a growing body of literature examining donor tissue microbiology, disease transmission, and postoperative infectious outcomes, it will be important for eye bank standards and screening to continue to reflect scientific evidence. Advocacy for tissue safety will need to be balanced with scrutiny of future regulatory standards in relation to their scientific basis and economic sustainability.

\section{Increasing responsibilities of eye banks}

Since the establishment of the first eye bank in 1944, the field of eye banking has changed dramatically. As such, eye banks have taken on increased responsibilities in terms of screening and processing tissue for transplant and research, donor eligibility, preparing precut allograft tissue, and embracing new technology and techniques.

\section{Donor screening and tissue evaluation process}

At time of death, eye bank personnel carefully review the donor's documented medical and social history, as well as contact the next of kin. Certified eye bank technicians perform a physical exam on deceased donors looking for physical evidence of infectious disease or high-risk behavior that would compromise their donor eligibility. Donors are screened and disqualified for donation based on a variety of risk factors (Table 3). ${ }^{17}$ Blood is drawn from the donor for serological testing and screening.
Once tissue has been transported to the local eye bank, the tissues are examined under slit lamp (for the presence of scars, Laser Assisted in Situ Keratomileusis (LASIK) flaps, edema, arcus, striae, epithelial defects, guttata, and so on), specular microscopy (to evaluate endothelial cell density and cell morphology), and pachymetry (to evaluate corneal thickness). Bacterial cultures may be performed at this time. Once tissues have been adequately evaluated and properly processed, they may be distributed to surgeons as fresh tissues in various preservation media (eg, Optisol GS, Life $4^{\circ} \mathrm{C}$, or Eusol C) for optical grafts and tectonic grafts, or occasionally glaucoma shunt devices. Otherwise, corneas are held intermediately at $4^{\circ} \mathrm{C}$ in the same media or prepared for long-term storage based upon anticipated use for transplant, research, or education. In other locations outside the US (particularly Europe), corneas are frequently stored in organ culture media at $\sim 37^{\circ} \mathrm{C}$.

\section{Adverse events}

In 1990, the EBAA instituted an adverse reaction-reporting system to provide "a method for the receiving surgeon to report adverse reactions from the transplantation of corneal, scleral or other ocular tissue to the source eye bank". ${ }^{25}$

This section will discuss different potential adverse events associated with corneal allograft transplantation and how various testing and screening performed by eye banks mitigate this risk by providing high quality and safe ocular tissue for donation. 


\section{Infectious disease and serology}

HIV

The AIDs epidemic of the 1980s increased concerns of transmission in the eye banking community. ${ }^{26}$ Medical history and serologic screens for HIV were implemented in the mid-1980s. ${ }^{25}$ These serologic tests were necessary due to the disparity in accuracy between historical and microbiological testing. Studies have estimated rates of serologic positivity for HIV in donors with grossly negative medical and social histories, ${ }^{27,28}$ with one group reporting rates of $0.4 \%$ for history-negative but eventual serologic HIV-positive donors. Currently, EBAA medical standards require negative testing for anti-HIV-1 and anti-HIV-2 assays.

To date there have been no reported cases of transmitted HIV through corneal grafts. This rate is upheld despite several reports of inadvertently transplanted corneas from HIV-positive donors into HIV-negative recipients. ${ }^{29,30}$ In all cases, there were zero cases of donor seroconversion despite receiving transplanted cornea from an infected donor. ${ }^{29,30}$

\section{Viral hepatitis}

Prior to the requirement for hepatitis testing, a report published in the early 1980s described two cases of HBV transmission through corneal transplantation. ${ }^{31}$ Currently, there are no documented reports of $\mathrm{HCV}$ transmission via corneal transplantation. However, the most current EBAA medical standards require serologic screening for both HBV (hepatitis B surface antigen assays) and HCV (anti-hepatitis $\mathrm{C}$ virus antibody assays). Rates of positive serologic testing in donors with negative histories for hepatitis are even higher than those of $\mathrm{HIV}^{27}$ with as many as $5.1 \%$ and $2.2 \%$ of history-negative donors with positive serologic tests for $\mathrm{HBV}$ and $\mathrm{HCV}$, respectively. ${ }^{28}$

In 2015 alone, 5,810 donated tissues were deemed unusable due to positive HBV serologic testing, making HBV the most common reason that tissue was rejected for transplant. Combining that number with the 2,725 cases of tissues from donors with positive HCV serologic testing, hepatitis accounted for over $25 \%$ of all tissue not released for transplant. ${ }^{3}$

\section{Other viruses}

Although EBAA medical standards only mandate viral serologic screening for $\mathrm{HIV}, \mathrm{HBV}$, and $\mathrm{HCV}$, there have been reports of other viruses transmitted from corneal grafts, including rabies ${ }^{32}$ and herpes simplex virus (HSV). ${ }^{33}$ Serologic testing for HSV is not required, although physical exam findings indicative of HSV infection are taken into consideration when determining a donor's eligibility. WNV nucleic acid testing has been proposed, ${ }^{21}$ but it is currently not required or routinely performed by eye banks. ${ }^{23}$ In March 2016, the FDA recommended against transplantation of organs from persons previously infected with Zika virus, ${ }^{34} \mathrm{a}$ practice that is currently implemented by eye banks.

\section{Syphilis}

Syphilis screening of donor tissue has become routine since FDA rulings in $1999 .{ }^{35}$ Currently, donors are screened using rapid plasma reagin serologic test for Treponema pallidum. If positive, donor tissue is not automatically excluded unless a confirmatory test (fluorescent treponemal antibody with absorption test) is also positive. ${ }^{17}$

Syphilis is difficult to transmit via corneal tissue. One study demonstrated an inability to infect healthy rabbits (both systemically and ocularly) with syphilis bacteria T. pallidum despite ocular and systemic inoculations of a syphilisinfected corneal concoction. ${ }^{36}$ In addition, T. pallidum loses infectivity potency when corneas are stored in standard storage materials. ${ }^{37}$ There have been no documented cases of transmitted syphilis from ocular tissue to date.

\section{Endophthalmitis}

There is risk for transmission of bacteria and fungi, leading to infectious keratitis and endophthalmitis. As such, tissue is often stored at cold temperature $\left(2-6^{\circ} \mathrm{C}\right)^{38}$ or in graft storage media (Optisol GS and Life $4^{\circ} \mathrm{C}$ ) containing gentamicin and streptomycin. ${ }^{39}$ Rates of postoperative yeast and fungal infections (keratitis or endophthalmitis) are also rising, although still quite low at 1.4 cases per 10,000 transplants performed, with most occurring after endothelial keratoplasties..$^{40}$ Aldave et al suggested that fungal (ie, Candida) infections occur twice as often after endothelial keratoplasty (EK) compared to penetrating keratoplasty (PK). ${ }^{40} \mathrm{~A}$ meta-analysis by Wilhelmus and Hassan estimated the risk of bacterial or fungal endophthalmitis to be $1 \%$ and $3 \%$, respectively, for transplanted corneas with bacterial or fungal culture-positive donors. $^{41}$

Studies have shown that transplanting tissue five or more days after donation appears to increase the risk of endophthalmitis. ${ }^{42,43}$ Despite the risks, most cornea allografts with pretransplanted positive bacterial cultures do not result in endophthalmitis or other postoperative infection, ${ }^{44}$ and eye banks still report low rates of bacterial contamination after technician recovered and prepared tissues. 


\section{Sepsis}

Sepsis, defined in 1992 by the American College of Chest Physicians, is a systemic response to infection and is the most common cause of death in noncoronary intensive care unit patients. ${ }^{45}$ Older reports expressed concern that corneal allografts obtained from donors with sepsis may lead to endophthalmitis ${ }^{46,47}$ As such, all tissues from donors diagnosed with sepsis at time of death are currently ineligible for transplantation. ${ }^{17}$ In 2015 , sepsis accounted for disqualification of $10.5 \%$ of the 33,577 tissues deemed unsuitable for transplantation, ${ }^{3}$ the second leading cause of tissue ineligibility behind HBV. Despite earlier reports, more recent studies have proposed safety of corneal allografts for transplantation from septic donors. ${ }^{48-50}$ Interestingly, the European Eye Bank Association does not automatically exclude corneal grafts from donors who have died from bacterial sepsis, but rather discards corneal tissue from those donors only if bacteria are cultured from the donated tissue. ${ }^{51}$

With new studies suggesting corneas from septic patients being suitable for transplantation, ${ }^{48-50}$ US eye banks may need to reevaluate whether to accept corneal tissue from septic donors.

\section{Noninfectious systemic disease transmission}

In addition to infection, corneal transplantation poses risks of transmission of noninfectious diseases, specifically malignancies and prion diseases. Current screening protocols have also kept the risk of these adverse events very low. However, carefully weighing potential risks against actual evidence of transmission remains an ongoing issue for eye bank leadership.

\section{Malignancy}

The risk of malignancy transmission via corneal transplantation is extremely low, even in donors with active malignancy. There have been five reports of tumor transmission through corneal transplantation. The first three included transmission of primary retinoblastoma in 1939,52 iris papillary adenocarcinoma (from bowel adenocarcinoma) in 2002,,$^{53,54}$ and a report of possible small cell carcinoma of the lung in 2003. ${ }^{55}$ Finally, in early 2016, two cases of melanoma and metastatic breast cancer transmission from a keratolimbal allografts were reported. ${ }^{53,56-58}$ Within 2 weeks of the melanoma report, a moratorium was temporarily placed on ocular tissue from donors with any history of melanoma and on vascularized ocular tissue from donors with any history of metastatic solid tumors. ${ }^{57}$ These restrictions were added to an amended EBAA medical standards by June 2016 .

\section{Prion disease}

Prions are infectious, transmissible, misfolded proteins that cause progressive neurologic deterioration and death. ${ }^{59}$ Because of a reported case of suspected prion-caused CJD transmission after a corneal transplant in $1974,{ }^{60}$ eye banks disqualify tissue from donors with suspected CJD. ${ }^{17}$ There have been no additional cases of post-corneal transplant CJD 5 due to screening guidelines. Donor "dementia" or "abnormal neurologic behavior prior to death" accounted for only $0.5 \%$ of unsuitable tissue in 2015 (180 corneas). ${ }^{3}$

\section{Precut tissue: from surgeon to technician}

Traditionally, corneal transplantation involved replacing the entire cornea with a full-thickness graft in a procedure called PK. However, advancement of surgical technique by surgeons such as Melles et a $\mathrm{l}^{61}$ and Terry and Ousley ${ }^{62}$ pioneered the way for lamellar procedures, replacing individual diseased layers rather than the entire cornea. New partial-thickness corneal transplantation procedures began to replace PK for anterior corneal diseases (eg, keratoconus) and posterior corneal diseases targeting endothelial cells (eg, Fuchs' dystrophy).

EK (replacement of the posterior endothelial layer of the cornea) has been the most commonly performed keratoplasty procedure in the US over the past four years, and it accounted for nearly $39 \%$ of the 79,304 national and international corneal transplants using US tissue in $2015 .^{3}$ These procedures traditionally involved the delivery of full-thickness corneal graft to the surgeon in the operating room, who would then dissect away the needed posterior cornea to create the specified endothelial graft. However, this step of tissue preparation added both time and cost to the procedures. ${ }^{63}$ These delays occurred for anterior lamellar surgeries as well. As such, eye banks recognized an opportunity to continue to streamline the process, by providing surgeons with "precut" corneal graft tissue. The first precut tissue by eye bank personnel began in $2006 .{ }^{64} \mathrm{With}$ eye banks taking on the responsibility to provide precut tissue, operating room workload was reduced, saving time and cost for both surgeons and medical centers. ${ }^{63}$

Initially, the shift from surgeon-prepared to eye technician-prepared grafts was met with trepidation. ${ }^{64}$ Surgeons were still responsible for the end outcomes of their procedures, and trusting the cutting and preparation of such delicate tissues to a non-surgeon required a change 
in paradigm. However, by 2008 , over half of all endothelial grafts were precut by eye bank personnel, ${ }^{4}$ demonstrating the growing trust and satisfaction of surgeons with eye bankprepared donor tissue.

Precut tissue can save between 13 and 21 minutes per procedure, ${ }^{63,65}$ leading to immense cost savings. ${ }^{63}$ Additionally, studies continue to demonstrate safety and efficacy of tissue prepared, cut, and processed by technicians compared to surgeons ${ }^{65-68}$ even for the technically difficult EKs.

\section{Descemet stripping endothelial keratoplasty (DSEK)} In 2000, Terry performed the first EK in the US, a procedure that coined deep lamellar EK. ${ }^{62}$ This technique involved transplantation of a posterior corneal lamella consisting of endothelium, Descemet membrane (DM), and overlying stromal tissue as an alternative to PK, resulting in quicker and safer visual recovery. ${ }^{69}$ This technique was refined in 2004 by Melles et al, by peeling or stripping the donor DM and endothelial layer, creating a smooth posterior stromal bed. This technique known as DSEK, ${ }^{61}$ further expedited visual recovery. ${ }^{69}$ Two years later, a microkeratome to dissect donor tissue was applied in a technique called Descemet stripping automated EK (DSAEK). By $2008,66 \%$ of all endothelial grafts for DSEK were precut by eyes banks. ${ }^{4}$ Multiple studies have demonstrated comparable tissue quality and positive surgical results from eye bank-prepared corneal tissue for DSEK..$^{65,68,70,71}$

In a study evaluating tissue quality of DSEK grafts $(n=197), 98 \%$ of eye bank-prepared grafts were deemed acceptable for surgery and were not associated with increased risk of complications due to tissue preparation. ${ }^{65}$ Terry noted that dislocation rates and postoperative endothelial cell density were also comparable for surgeon versus eye bank-prepared tissue. ${ }^{72}$

Additionally there is a cost benefit for using precut corneas for DSEK. Although corneal donations are a free gift from donors, there are costs associated with tissue processing that are reimbursed to eye banks (Table 4). For example, an eye bank fee for PK tissue is approximately $\$ 2,900-\$ 3,100$, which can increase to about $\$ 3,600-\$ 3,750$ for DSAEK due to the additional processing. ${ }^{73}$ Although these fees make up approximately $40 \%$ of the total costs associated with transplantation, ${ }^{73}$ use of eye bank services is actually time and cost-effective for surgeons and patients. Yong et al demonstrated that purchasing precut corneas from eye banks saved over $\$ 1,300$, largely due to decreased procedure duration. ${ }^{63}$ This analysis also recommended that high-volume corneal transplant facilities performing more than 290 cases annually could maximize cost savings by setting up their own precutting facility. ${ }^{63}$
Table 4 Eye bank processing fees (Approximate fees from Lions Vision Graft Eye Bank, Portland, OR, USA)

\begin{tabular}{ll}
\hline Tissue type & Fees \\
\hline Comea base* & $\$ 3,100$ \\
KLAL & $\$ 3,100$ \\
\hline Additional fees for precut tissue & \\
\hline ALK & $\$ 650$ \\
DSAEK & $\$ 650$ \\
DMEK & $\$ 850$ \\
FLAK & $\$ 1,200$ \\
Glaucoma shunt covers & \\
Sclera & $\$ 350$ \\
Cornea & $\$ 400$ \\
\hline
\end{tabular}

Notes: *Used for penetrating keratoplasty (PK). The fees reimbursed to eye banks for various types of corneal graft tissue are described.

Abbreviations: ALK, anterior lamellar keratoplasty; DSAEK, descemet stripping automated endothelial keratoplasty; DMEK, descemet membrane endothelial keratoplasty; FLAK, femtosecond laser assisted keratoplasty; KLAL, keratolimbal allograft.

\section{Descemet membrane endothelial keratoplasty (DMEK)}

In 2006, Melles et al further refined their proposed DSEK technique by creating a "stroma-free" DSEK-like graft, consisting solely of endothelial and overlying DM. ${ }^{74}$ This thin graft $(10-15 \mu \mathrm{m})$ is used in the DMEK procedure or its newer counter-part called pre-Descemet endothelial keratoplasty. ${ }^{75}$

DMEK has been slowly accepted due to the associated challenges of preparing and handling the delicate graft tissue. ${ }^{76}$ Different techniques have been developed to isolate thin endothelium and overlying DM, including peeling, ${ }^{77}$ pneumatic dissection, ${ }^{76}$ and femtosecond lasers (FSLs). ${ }^{78}$

Peeling involves an initial incision into corneal endothelium and then gently stripping DM from the overlying stroma with forceps, leaving a sheet of DM and intact underlying endothelial monolayer. ${ }^{77}$

Pneumatic dissection separates DM from the stroma by injecting air into the paracentral cornea, thus creating a dissection plane between DM and the stroma. ${ }^{75,76}$ Recent studies modifying this technique have also reported use and advantages of a liquid bubble for initial dissection. ${ }^{79}$ In comparison studies, peeling and pneumatic dissection appear to obtain equal-quality DM and endothelial cell loss. ${ }^{80}$

Several studies have noted that eye bank-prepared DMEK tissues demonstrated outcomes comparable to surgeonprepared tissue in terms of visual acuity, graft failure rate, and endothelial cell loss. ${ }^{66,67}$ Additionally, studies have found that corneas from patients with diabetes mellitus, hyperlipidemia, and obesity were more likely to tear with dissection. ${ }^{81,82}$ Adverse event rates could be reduced by $3 \%$ by eliminating tissue donation from diabetic and obese donors, ${ }^{81}$ 
although this may not be practical given the prevalence of these diseases. Ultimately, these are important parameters for eye banks to consider when evaluating quality of tissue for DMEK preparation.

As the number of DMEK procedures continues to rise, there will be an increasing burden placed upon eye banks. Not only will this require increased training, skill, and precision from eye bank technicians, but the fragility of the tissue could result in more tissue wasting by both transplanting surgeons and tissue-preparing technicians ${ }^{64}$ However, because DMEK utilizes only a thin posterior corneal lamella, there is a myriad of opportunities to save on tissue waste and cost. Single corneas can be "shared" between patients, as one study reported splitting a single whole cornea into anterior and posterior lamellar tissues to be utilized for both DMEK and deep anterior lamellar keratoplasty (DALK) procedures in separate patients. ${ }^{83}$ In addition, Lam et al have described halving the thin DMEK endothelial tissue to create semicircle hemi-DMEK grafts that may have comparable visual outcomes to traditional DMEK, thereby doubling the pool of potential donor endothelial tissue for DMEK surgery. ${ }^{84}$ As eye banks rise to the challenge of increasingly refined surgery and escalating surgeon expectations, adoption of new techniques can become more widespread, with greater financial and surgical efficiency.

\section{Special procedures}

\section{Preloaded keratoplasty grafts}

Minimizing endothelial cell loss during intraocular delivery of endothelial grafts is challenging. Eye banks have begun exploring the concept of tissue that is preloaded (eg, scrolled and folded) into intraocular injectors for surgeon ease and efficiency, ${ }^{85}$ providing less intraoperative tissue manipulation. Although initial studies have shown this practice to be successful, ${ }^{85}$ direct comparison between preloaded grafts performed by eye banks versus grafts loaded by surgeons has not been published.

\section{Femtosecond lasers}

The FSL was introduced in the late 1990 s by Juhasz ${ }^{86,87}$ and was initially used for LASIK flap creation. ${ }^{88}$ Since then, its use has been expanded to cataract surgery, and penetrating, lamellar, and endothelial keratoplasties. ${ }^{78,89}$ For penetrating and lamellar keratoplasties, FSL allows surgeons to create more diverse cuts for better overlap between donor and recipient tissues, leading to decreased astigmatism, improved stability, less perioperative pain, and faster healing times. ${ }^{86,90}$ Currently, its use includes preparation of donor and recipient corneas for use in PK, ALK, DALK, and EK. ${ }^{86}$
The application of FSL-prepared grafts for endothelial transplant is still developing. The alternative to FSL corneal preparation is the use of microkeratomes, which utilize a blade to make a clean corneal incision. Various studies have compared current FSL technology to microkeratome for donor tissue dissection for both DSAEK ${ }^{91}$ and DMAEK procedures. ${ }^{78}$ Use of FSL for DSAEK grafts appears to be inferior to microkeratome dissections, resulting in thicker endothelial discs with rougher stromal beds, ${ }^{91,92}$ which may lead to irregular astigmatisms, increased interface irregularity, and poor visual outcomes. ${ }^{93}$ These limitations may be overcome with the addition of an excimer laser, creating a smooth, high-quality interface in a novel technique called femtosecond and excimer laser-assisted endothelial keratoplasty. ${ }^{94}$

Use of FSL for DMAEK preparation is a new area of study. Jardine et al reported that FSL may lead to more consistent and precise endothelial dissections, but these grafts may be more prone to endothelial cell loss. This novel technique is also highly dependent upon user experience. ${ }^{78}$

In addition to its questionable clinical advantages, cost remains a major prohibitive barrier to full adaptation of FSL technology into routine eye banking. A few eye banks in the US use FSL technology for tissue preparation. The cost of the laser apparatus is approximately $\$ 500,000$ with additional "click fees" per tissue cut at a rate of $\sim \$ 200$ as well as up to $\$ 50,000$ in annual maintenance contracts. ${ }^{95}$ In addition, even after obtaining FSL-prepared PK tissue cut with a specific pattern, many PK surgeons do not have access to FSL to make the complementary incisions required on their patients or utilize a different type of FSL in their practice.

In addition to cost and access issues, more data are needed to demonstrate consistent, clear, clinical benefits of FSL technology, before FSL is more largely incorporated into routine eye banking preparation of corneal tissue. ${ }^{86}$

\section{Keratolimbal allografts (KLALs)}

KLAL uniquely utilizes corneal tissue for limbal stem cell deficiency (LSCD), requiring specific procurement and preparation of graft tissue by eye bank technicians. KLAL accounts for $0.13 \%$ of all transplanted corneal grafts. Limbal stem cells are responsible for the healthy function of corneal epithelium. ${ }^{96}$ When these cells are damaged or destroyed (resulting in LSCD), the surrounding conjunctiva invades and replaces the corneal epithelium in a process called "conjunctivalization", leading to severe irritation, photophobia, and decreased vision. Traditional corneal transplants do not do well at mending this condition, so treatment is alternatively aimed at replacing the lost limbal stem cells. ${ }^{96}$ In addition to LCSD, KLAL tissue is used for ocular surface 
reconstruction as an alternative to amniotic membrane or conjunctival allografts. ${ }^{97}$

KLAL has unique requirements compared to other standard grafting procedures. Tissue from pediatric or young adult donors is optimal. Additionally, recovery technicians are asked to preserve a conjunctival peripheral skirt and at least $4-5 \mathrm{~mm}$ of corneoscleral rim to minimize damage to the limbus. ${ }^{98}$

Limbal stem cells are more sensitive to longer storage times ${ }^{99}$ and must be quickly transplanted after a donor's death, preferably within 72 hours. ${ }^{98}$ Additionally, KLAL often requires two corneas from the same donor to be successful. KLAL and other procedures with specific tissue requirements demonstrate both the need for and ability of eye banks to remain adaptable to tissue procurement and handling.

\section{Patch grafting and glaucoma shunts}

Corneas have recently been used as patch grafts for glaucoma drainage tubes. Three percent of manufactured glaucoma drainage implants (GDIs) experience tube erosion from the overlying conjunctiva. ${ }^{100,101}$ GDIs can create a conduit by which normal bacterial flora may pass from the ocular surface into the eye, increasing the risk of endophthalmitis. ${ }^{102}$ Previous studies have used donor dura, sclera, pericardium, fascia lata, porcine intestinal mucosa, and amniotic membrane as patch grafts for these tube erosions. ${ }^{101,103}$ Corneal patch grafts have also been used for leaky scleral flaps following trabeculectomy. ${ }^{104}$

Corneas are preferred over other tissue for their remarkable tensile strength, transparency, and ease of surgical use. ${ }^{100}$ Corneal clarity also improves patch graft cosmesis and enhances tube visualization for further procedures, ${ }^{105}$ although grafts may eventually become edematous or vascularized with time.

Recovered tissue undergoes gamma irradiation (tissues are loaded into irradiator machines where radioactive isotopes are used to create gamma rays) to create a sterile cornea, free of bacterial, viral, or fungal disease transmission, ${ }^{100}$ making them more safe than fresh, non-sterilized human corneas. ${ }^{103}$ Gamma radiation also kills all living cells in corneal tissue and corneal alternatives (e.g., pericardium and sclera) meaning these irradiated tissues can only be used for structural procedures that do not require cellular function. ${ }^{106}$ Alternatively, electron beam technology has been used to create sterile corneas without using radioactivity. ${ }^{107}$ Sterile corneal allografts can be stored at room temperature for at least 18 months ${ }^{100}$ as they are used as a mechanical covering and seal, rather than for optical and visual purposes. Although precise clarity and refractive accuracy is not a functional component of the patch graft, its persistently adequate clarity allows for postoperative examination of GDI tubes and sutures, ${ }^{100}$ as well as postoperative laser suture lysis. It has been estimated that approximately $40 \%$ of donated corneas are discarded for various reasons, including unhealthy endothelium. ${ }^{4}$ As such, the use of corneas for patch grafting in GDIs creates a niche for previously unsuitable donor cornea based on the irrelevancy of a functional endothelium.

Going forward, eye banks may encounter challenges with widespread training and use of this technology. Tissue Banks International currently has a patent pending on their gamma-irradiated cornea VisionGraft, which may prevent adoption of this preservation technique by other eye banks.

\section{Barriers to corneal donation Religion}

Although eye donation is considered noble in many populations, ${ }^{108}$ some religious beliefs are resistant to eye donation. ${ }^{109}$ Views of the afterlife, resurrection, reincarnation, or other religious perspectives may influence or deter one from donating. ${ }^{110}$ Sensitivity to and understanding of these cultural and religious views can help facilitate discussion of corneal donation with families.

\section{Public education}

Lack of public awareness is often the major obstacle to corneal procurement. ${ }^{110}$ Many countries have publicly funded programs to help raise awareness. In developing countries, the task of public education is often left to non-government organizations. It is also imperative for health care workers to improve their communication skills regarding tissue donation. ${ }^{111}$ As the public understands the need for and process of corneal transplantation, there may be a greater willingness to participate in tissue donation.

\section{Eye banking in developing countries}

Eye banking in developing countries is improving, but it is still limited by several barriers including trained staff, affordability of equipment and storage media cost, and inadequate public awareness. ${ }^{112}$ Despite these barriers, transplant rates are rising in many of these countries. Less-expensive corneal storage media (eg, Cornisol; Aurolab, Madurai, Tamil Nadu, India) is being used in India and neighboring countries, decreasing storage costs by nearly $65 \% .{ }^{112}$ Additionally, countries such as Brazil and the Philippines have adopted legislation similar to the US, requiring hospitals to identify 
potential donors at time of death or deem deceased as "presumed" donors unless prevented by next of kin. ${ }^{12,113}$ Finally, eye banks in India and the Philippines began to precut tissue in 2012 and 2013, respectively. ${ }^{112}$ These advancements, as well as provision and donation of tissues from developed countries, have helped improve accessibility of corneal transplantation in many developing countries.

\section{The future of eye banking}

\section{Tissue cultures}

Although eye banks have provided sufficient numbers of corneas to meet national demand, there remains a shortage of transplantable corneal tissue worldwide. ${ }^{2}$ This disparity is compounded by the increasing demand toward the more labor-intensive EK tissue over traditional PK.

Currently, surgical treatment for endotheliopathies, such as Fuchs' dystrophy, has been limited to PK or endothelial keratoplasty. As such, research focused on the use of stem cells to replace damaged endothelium with new, functional endothelium is on the rise. Some labs have reported in vitro success of regenerating endothelium; however, this activity could not be replicated in vivo. ${ }^{114,115}$ One study engineered human corneal endothelial cells (HCEC) that exhibited $75-95 \%$ pump function as normal human cornea donors. ${ }^{116}$ These HCECs were also used to perform successful endothelial grafts in rabbits via DSEK technique, ${ }^{117}$ and has been replicated by others in animal models using DSEK and DSAEK techniques. ${ }^{116,118,119}$ Once successfully grown, delivery of these cultured endothelial stem cells remains a daunting obstacle. There have been no successfully grown and transplanted HCECs in humans to date.

In addition to endothelial cells, culturing epithelium has also been attempted. One Italian eye bank has been involved in culturing limbal epithelial stem cells for research purposes. ${ }^{120,121}$

In order to integrate tissue cultures into eye banking practice, eye banks would need trained personnel for culturing endothelial ${ }^{116}$ and epithelial cells, ${ }^{120,121}$ careful construction of cell sheets to be used for transplantation, ${ }^{116,122}$ and delicate transport for transplantation, requiring expertise and increased resources. Further research to optimize culture growth protocols as well as successful delivery of these cultures is necessary before they can be used in a clinical setting. ${ }^{114}$ There are also many regulatory barriers to the commercial production of transplantable cultured corneal tissues in some countries including the US. Despite these barriers, tissue cultures may serve as an adjunct to donor tissue for endothelial and epithelial corneal transplants in the future.

\section{Bioengineered corneas}

Bioengineering of tissues and even organs has gained increasing attention over the past decade. Currently, researchers are seeking to develop various types of organs including bone, skin, blood vessels, and even whole organs such as liver. ${ }^{123}$ Application of tissue and organ bioengineering has been extended into the realm of corneal allo/ auto graft creation. This process involves the growth of individual cell lines, as well as the development of associated cellular scaffolding for tissue growth. ${ }^{124}$ The past two decades have shown promise in cornea bioengineering. In 1999, Griffith et al constructed corneal epithelial, stromal, and endothelial equivalents to be used for drug testing and biomedical research. These corneal equivalents mimicked human corneal morphology, biochemical marker expression, transparency, ion and fluid transport, and gene expression. ${ }^{125}$

Other groups have constructed these "self-assembled" corneal substitutes by inducing keratocytes with ascorbic acid to produce and secrete stromal-like extracellular matrix macromolecules. ${ }^{126,127}$ Although hopeful, this "growing" approach is currently limited by time and expense, as it takes an average of four weeks to produce a mere $36 \mu \mathrm{m}$ of tissue. ${ }^{127}$

In 2008, a Swedish group performed an ALK on ten patients with keratoconus using $500 \mu \mathrm{m}$-thick biosynthetic corneal substitutes composed of recombinant human collagen. ${ }^{128}$ Although some patients exhibited implant thinning and fibrosis, no signs of stromal edema, neovascularization, prolonged inflammation, or signs of rejection were reported in any of the patients throughout the entirety of the 24-month study period. Tear film layers were restored, keratocytes were recruited into the implant, and reepithelialization (often the most important factor for reducing postoperative complications in keratoprosthesis) also occurred in all ten patients. Vision improved in six patients compared to preoperative screening. ${ }^{128}$

Although early results appear promising, there are likely to be future technical challenges involving the integration and commercialization of tissue culture techniques into eye banks. Culturing tissue is a more "laboratory-intense" process than preparing procured tissue, which will require additional training and expertise. Additionally, storage, manipulation, and transportation of these bioengineered cornea substitutes will likely pose a challenge to eye banks. Finally, successfully cultured tissues will be subject to strict scrutiny by the FDA and other regulatory agencies prior to their clinical debut. ${ }^{129}$ 


\section{Corneal lenticules for refractive procedures}

Recent applications of FSLs and alternatives to LASIK refractive surgery have been developed. Small incision lenticular extraction (SMILE) is a growing LASIK alternative with nearly 400,000 procedures performed worldwide to date. ${ }^{130}$ SMILE is the process of removing a stromal lenticule via FSL and subsequent manual dissection, improving refraction for myopic patients. ${ }^{131}$

With the growing use of this technique, some groups have examined the possible use of the refractive lenticules in hyperopia, ${ }^{132}$ keratoconus, ${ }^{133}$ and reimplantation after SMILE. ${ }^{134}$ Early studies evaluating safety and outcomes of lenticular implants have been promising. ${ }^{132}$

However, the process of lenticular preparation storage and after initial extraction is not straightforward. Corneal lenticules must be decellularized to prevent graft rejection ${ }^{130}$ and then stored in a manner to preserve tissue integrity. ${ }^{135}$ Currently, lenticules are measured to estimate refractive power and then matched to appropriate patients. ${ }^{135}$ Future eye banking applications may include shaping of stromal lenticules by FSL to produce more exact refractive outcomes and generat- ing large libraries of such lenticules for widespread surgical distribution. However, the cost associated with such production may limit this technique to specific eye bank centers. This novel technique is still in its infancy, and more studies are required to support its clinical application, success, and safety.

\section{Conclusion}

From Zirm's first corneal transplant in 1905 to the advent of partial thickness corneal grafts, and into the future possibilities of growing corneas in a petri dish, the field of eye banking remains one of constant change (Figure 4). Eye banks have repeatedly risen to new challenges regarding safety, necessity of partial thickness graft preparation, use of novel technology, and adjusting to meet increasing legislation and regulation. Once a mere convenience and solution to corneal graft supply and demand disparity, eye banks now play an equal and imperative role in overseeing, coordinating, and advancing corneal transplantation services. Without eye banks, corneal transplantation would not be as safe, efficient, or feasible as it is today. As eye banks continually rise to meet future challenges, the future of corneal transplantation will remain "clear".

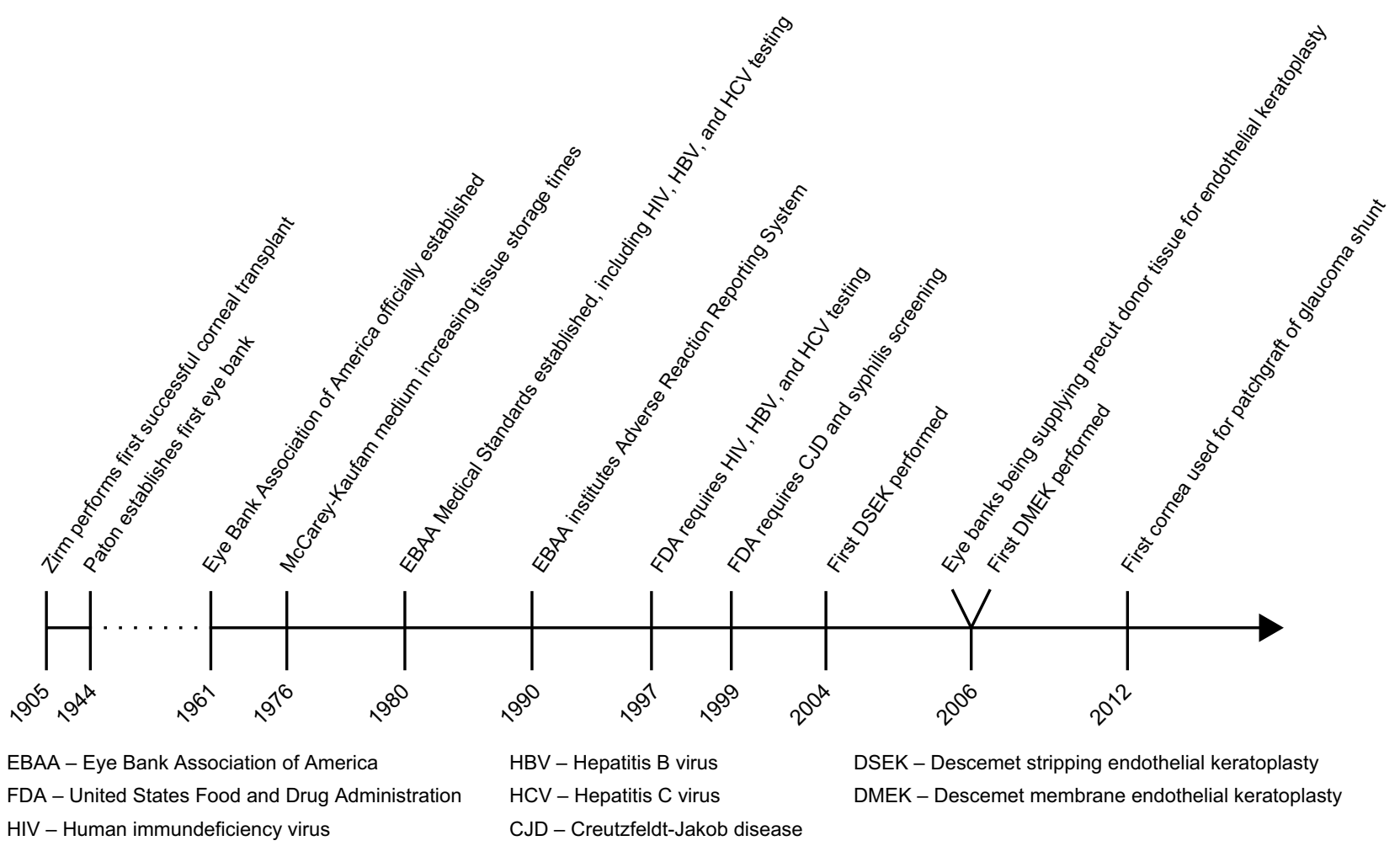

Figure 4 Timeline of eye banking in the US.

Note: The key events in the history of eye banking and corneal surgery are represented in this figure. 


\section{Acknowledgments}

We would like to personally thank Stacey Gardner (EBAA, Director of Education) and Chris Stoeger (Lions VisionGift, Director of Operations, Portland, OR) for their contribution of knowledge and resources to the preparation of this manuscript.

\section{Author contributions}

Winston Chamberlain has had full access to all the data in the study and takes responsibility for the integrity of the data. All authors contributed toward data analysis, drafting and revising the paper and agree to be accountable for all aspects of the work.

\section{Disclosure}

The authors report no conflicts of interest in this work.

\section{References}

1. Pascolini D, Mariotti SP. Global estimates of visual impairment: 2010. Br J Ophthalmol. 2012;96(5):614-618.

2. Gain P, Jullienne R, He Z, et al. Global survey of corneal transplantation and eye banking. JAMA Ophthalmol. 2016;134(2):167-173.

3. Eye Bank Association of America. 2015 Eye Banking Statistical Report. Washington, DC: EBAA; 2016. Available from: http://restoresight.org/wp-content/uploads/2016/03/2015-Statistical-Report.pdf. Accessed August 8, 2016.

4. Eye Bank Association of America. 2009 Eye Banking Statistical Report. Washington, DC: EBAA; 2009. Available from: http://www. corneas.org/repository/images/pressimages/EBAA\%202009\%20 Statistical\%20Report\%20-\%20Final.pdf. Accessed August 8, 2016.

5. Chu W. The past twenty-five years in eye banking. Cornea. 2000; 19(5):754-765.

6. Zirm EK. Eine erfolgreiche totale keratoplastik (A successful total keratoplasty). 1906. Refract Corneal Surg. 1989;5(4):258-261.

7. Armitage WJ, Tullo AB, Larkin DF. The first successful full-thickness corneal transplant: a commentary on Eduard Zirm's landmark paper of 1906. Br J Ophthalmol. 2006;90(10):1222-1223.

8. Elschnig A, Vorisek EA. Keratoplasty. Arch Ophthalmol. 1930; 4(2):165-173.

9. Espandar L, Carlson AN. Lamellar keratoplasty: a literature review. J Ophthalmol. 2013;2013:894319.

10. EBAA. History of Corneal Transplantation, Eye Banking and the EBAA. Washington, DC: EBAA; 2012. Available from: http://www. restoresight.org/wp-content/uploads/2012/02/History-CornealTransplants-Eye-Banking-and-the-EBAA.pdf. Accessed August 8, 2016.

11. Coster DJ. History of corneal transplantation in Australia. Clin Exp Ophthalmol. 2015;43(3):268-276.

12. Narayan RP. Development of tissue bank. Indian J Plast Surg. 2012;45(2):396-402.

13. Strong DM. The US Navy Tissue Bank: 50 years on the cutting edge. Cell Tissue Bank. 2000;1(1):9-16.

14. Jones GL, Ponzin D, Pels E, Maas H, Tullo AB, Claerhout I. European eye bank association. Dev Ophthalmol. 2009;43:15-21.

15. Eye Bank of Canada. Can Fam Physician. 1967;13(9):75.

16. EBAANZ. National Guidelines. Eye Bank Association of Australia and New Zealand [homepage on the Internet]. 2017. Available from: http://www.ebaanz.org/wp-content/uploads/2016/03/EBAANZNATIONAL-GUIDELINES-2016-For-the-care-and-handlingof-HTO-FINAL.pdf. Accessed March 8, 2017.
17. Eye Bank Association of America. 2015 Eye Banking Medical Standards. Washington, DC: EBAA; 2016. Available from: http:// restoresight.org/wp-content/uploads/2016/03/2015-Statistical-Report. pdf. Accessed August 10, 2016.

18. Eye Bank Association of America. Constitution and Bylaws. Washington, DC: EBAA; 2015. Available from: http://restoresight.org/ wp-content/uploads/2015/05/Bylaws-Final.pdf. Accessed December 19,2016

19. FDA. Human tissue intended for transplantation - final rule. Fed Regis. 1997;62(145):40429-40447.

20. Department of Veterans Affairs. Payment for inpatient and outpatient health care professional services at non-departmental facilities and other medical charges associated with non-VA outpatient care. Fed Regist. 2010;75(242):78901-78915.

21. Food and Drug Administration (FDA). Draft guidance for industry: use of nucleic acid tests to reduce the risk of transmission of West Nile virus from donors of human cells, tissues, and cellular and tissue-based products. 2013; ID: FDA-2013-D-1143-0002. Available from: https:// www.regulations.gov/document?D=FDA-2013-D-1143-0002. Accessed August 8, 2016.

22. Greenwald MA, Kuehnert MJ, Fishman JA. Infectious disease transmission during organ and tissue transplantation. Emerg Infect Dis. 2012;18(8):e1.

23. Corcoran KP. Letter to the FDA regarding "Draft guidance for industry: use of nucleic acid tests to reduce the risk of transmission of West Nile virus from donors of human cells, tissues, and cellular and tissue-based products". January 21, 2014. Available from: http:// restoresight.org/wp-content/uploads/2014/01/EBAA-Final-Comments-Draft-Guidance-Use-of-Nucleic-Acid-Tests-To-Reduce-theRisk-of-Transmission-of-West-Nile-Virus-From-Donors-of-HCT-Ps. pdf. Accessed November 1, 2016.

24. Glasser DB. Serologic testing of cornea donors. Cornea. 1998;17(2):123-128.

25. Aiken-O'Neill P. Letter to FDA regarding "Draft guidance for industry: preventive measures to reduce the possible risk of transmission of Creutzfeldt-Jacob disease (CJD) and variant Creutzfeldt-Jakob disease (vCJD) by human cells, tissues, and cellular and tissue-based products". 2002. Available from: http://www.fda.gov/ohrms/dockets/ dailys/02/Dec02/122402/80043a70.pdf. Accessed August 8, 2016.

26. Heck E, Petty C, Palestine A, et al. ELISA HIV testing and viral culture in the screening of corneal tissue for transplant from medical examiner cases. Cornea. 1989;8(2):77-80.

27. Armstrong SA, Gangam N, Chipman ML, Rootman DS. The prevalence of positive hepatitis $\mathrm{B}$, hepatitis $\mathrm{C}$, and HIV serology in cornea donors prescreened by medical and social history in Ontario, Canada. Cornea. 1997;16(5):512-516.

28. Heck E, Brown A, Cavanagh HD. Nucleic acid testing and tissue safety: an eye bank's five-year review of HIV and hepatitis testing for donor corneas. Cornea. 2013;32(4):503-505.

29. Caron MJ, Wilson R. Review of the risk of HIV infection through corneal transplantation in the United States. J Am Optom Assoc. 1994;65(3):173-178.

30. Simonds RJ, Holmberg SD, Hurwitz RL, et al. Transmission of human immunodeficiency virus type 1 from a seronegative organ and tissue donor. New Engl J Med. 1992;326(11):726-732.

31. Hoft RH, Pflugfelder SC, Forster RK, Ullman S, Polack FM, Schiff ER Clinical evidence for hepatitis B transmission resulting from corneal transplantation. Cornea. 1997;16(2):132-137.

32. Houff SA, Burton RC, Wilson RW, et al. Human-to-human transmission of rabies virus by corneal transplant. New Engl J Med. 1979;300(11):603-604.

33. Cleator GM, Klapper PE, Dennett C, et al. Corneal donor infection by herpes simplex virus: herpes simplex virus DNA in donor corneas. Cornea. 1994;13(4):294-304.

34. Available from: https://www.fda.gov/downloads/biologicsbloodvaccines/guidancecomplianceregulatoryinformation/guidances/tissue/ ucm488582.pdf. Accessed March 8, 2017. 
35. Food and Drug Administration, HHS. Suitability determination for donors of human cellular and tissue-based products-proposed rule. Fed Regist. 1999;64(189)52696-52723.

36. Randolph ME. An experimental study of the possibility of transmitting syphilis by a corneal graft. Trans Am Ophthalmol Soc. 1949;47:683-691.

37. Macsai MS, Norris SJ. OptiSol corneal storage medium and transmission of Treponema pallidum. Cornea. 1995;14(6):595-600.

38. Pels E, Beele H, Claerhout I. Eye bank issues: II. Preservation techniques: warm versus cold storage. Int Ophthalmol. 2008;28(3):155-163.

39. Varner AC, Rich LF, Crow BL, MacRae S. Survival of streptococcus in optisol-GS medium. J Refract Surg. 1995;11(3):207-209.

40. Aldave AJ, DeMatteo J, Glasser DB, et al. Report of the Eye Bank Association of America medical advisory board subcommittee on fungal infection after corneal transplantation. Cornea. 2013;32(2):149-154.

41. Wilhelmus KR, Hassan SS. The prognostic role of donor corneoscleral rim cultures in corneal transplantation. Ophthalmology. 2007;114(3):440-445.

42. Hassan SS, Wilhelmus KR, Dahl P, et al; Medical Review Subcommittee of the Eye Bank Association of America. Infectious disease risk factors of corneal graft donors. Arch Ophthalmol. 2008;126(2):235-239.

43. Antonios SR, Cameron JA, Badr IA, Habash NR, Cotter JB. Contamination of donor cornea: postpenetrating keratoplasty endophthalmitis. Cornea. 1991;10(3):217-220.

44. Gandhi SS, Lamberts DW, Perry HD. Donor to host transmission of disease via corneal transplantation. Surv Ophthalmol. 1981;25(5):306-311.

45. Bone RC, Balk RA, Cerra FB, et al. Definitions for sepsis and organ failure and guidelines for the use of innovative therapies in sepsis. The ACCP/SCCM Consensus Conference Committee. American College of Chest Physicians/Society of Critical Care Medicine. Chest. 1992;101(6):1644-1655.

46. Chaurasia S, Muralidhar R, Garg P, Gopinathan U. Donor corneal button-related endophthalmitis after penetrating keratoplasty. Clin Exp Ophthalmol. 2010;38(1):75-76.

47. Khodadoust AA, Franklin RM. Transfer of bacterial infections by donor cornea in penetrating keratoplasty. Am J Ophthalmol. 1979;87(2):130-132.

48. Acharya M, Mathur U, Dave A. Evaluation of corneas from donors with septicemia for use in corneal transplant. Cornea. Epub 2016 Oct 14.

49. Mathur U, Acharya M, Garg J, Sapra N, Chauhan L. Risk of transmission of infection to host from septicaemic donor corneas. Int J Eye Bank. 2015;3(3):1-5.

50. Nagaraja H, Anandula V, Kugar T, Shivanna Y, Shetty R. Evaluation of corneas from donors with septicemia for use in corneal transplant. Cornea. 2016;35(8):1132-1135.

51. EEBA. European Eye Bank Association Statement on Pre-Processing Microbiology Testing in Eye Banks; 2009. Available from: http://www. europeaneyebanks.org/files/Statement_on_pre-processing_microbiology_testing_in_eye_banksFinalGJ.pdf. Accessed November 1, 2016.

52. Hata B. The development of glioma in the eye to which the cornea of patient, who suffered from glioma was transplanted. Acta Soc Ophthalmol Jpn. 1939;43:1763-1767.

53. Li JY. Donors with melanoma history: the risk to ocular tissue recipients. Int J Eye Bank. 2016;4(1):1-4.

54. McGeorge AJ, Vote BJ, Elliot DA, Polkinghorne PJ. Papillary adenocarcinoma of the iris transmitted by corneal transplantation. Arch Ophthalmol. 2002;120(10):1379-1383.

55. Floren I. Transmission of malignancy by corneal transplantation. Paper presented at: 15th Conference for European Eye Bank Association; January 22, 2003; Brussels, Belgium.

56. Holland E. Conjunctival-limbal melanoma after a keratolimbal allograft. Paper presented at: Cornea Society Fall Educational Symposium; October 14, 2016; Chicago, IL.
57. Li JY. EBAA major guidance and standards changes. Int J Eye Bank. 2016;4(2):1-3.

58. Miller AK, Young JW, Wilson DJ, Dunlap J, Chamberlain W. Transmission of donor-derived breast carcinoma as a recurrent mass in a keratolimbal allograft. 2017. doi: 10.1097/ICO.0000000000001185.

59. Prusiner SB. Prions. Proc NatlAcad Sci USA. 1998;95(23):13363-13383.

60. Duffy P, Wolf J, Collins G, DeVoe AG, Streeten B, Cowen D. Letter: possible person-to-person transmission of Creutzfeldt-Jakob disease. New Engl J Med. 1974;290(12):692-693.

61. Melles GR, Wijdh RH, Nieuwendaal CP. A technique to excise the descemet membrane from a recipient cornea (descemetorhexis). Cornea. 2004;23(3):286-288.

62. Terry MA, Ousley PJ. Deep lamellar endothelial keratoplasty in the first United States patients: early clinical results. Cornea. 2001;20(3):239-243.

63. Yong KL, Nguyen HV, Cajucom-Uy HY, et al. Cost minimization analysis of precut cornea grafts in descemet stripping automated endothelial keratoplasty. Medicine (Baltimore). 2016;95(8):e2887.

64. Li JY, Mannis MJ. Eye banking and the changing trends in contemporary corneal surgery. Int Ophthalmol Clin. 2010;50(3): $101-112$.

65. Kitzmann AS, Goins KM, Reed C, Padnick-Silver L, Macsai MS, Sutphin JE. Eye bank survey of surgeons using precut donor tissue for descemet stripping automated endothelial keratoplasty. Cornea. 2008;27(6):634-639.

66. Guerra FP, Anshu A, Price MO, Giebel AW, Price FW. Descemet's membrane endothelial keratoplasty: prospective study of 1-year visual outcomes, graft survival, and endothelial cell loss. Ophthalmology. 2011;118(12):2368-2373.

67. Ham L, Dapena I, van Luijk C, van der Wees J, Melles GR. Descemet membrane endothelial keratoplasty (DMEK) for Fuchs endothelial dystrophy: review of the first 50 consecutive cases. Eye (Lond). 2009;23(10):1990-1998.

68. Rose L, Briceño CA, Stark WJ, Gloria DG, Jun AS. Assessment of eye bank-prepared posterior lamellar corneal tissue for endothelial keratoplasty. Ophthalmology. 2008;115(2):279-286.

69. Doughman DJ, Rogers CC. Eye banking in the 21 st century: how far have we come? Are we prepared for what's ahead? Int J Eye Bank. 2012;1(1):1-15.

70. Katzman LR, Hoover CK, Khalifa YM, Jeng BH. Assessment of the accuracy and cut-failure rates of eye bank-cut corneas for use in endothelial keratoplasty: a comparison of outcomes between 2010 and 2013. Cornea. 2015;34(11):1365-1368.

71. Price MO, Baig KM, Brubaker JW, Price FW Jr. Randomized, prospective comparison of precut vs surgeon-dissected grafts for descemet stripping automated endothelial keratoplasty. Am J Ophthalmol. 2008;146(1):36-41.

72. Terry MA. Endothelial keratoplasty: a comparison of complication rates and endothelial survival between precut tissue and surgeoncut tissue by a single DSAEK surgeon. Trans Am Ophthalmol Soc. 2009;107:184-191.

73. Prabhu SS, Kaakeh R, Sugar A, Smith DG, Shtein RM. Comparative cost-effectiveness analysis of descemet stripping automated endothelial keratoplasty versus penetrating keratoplasty in the United States. Am J Ophthalmol. 2013;155(1):45-53. e1.

74. Melles GR, Ong TS, Ververs B, van der Wees J. Descemet membrane endothelial keratoplasty (DMEK). Cornea. 2006;25(8):987-990.

75. Agarwal A, Dua HS, Narang P, et al. Pre-Descemet's endothelial keratoplasty (PDEK). Brit J Ophthalmol. 2014;98(9):1181-1185.

76. Boynton GE, Woodward MA. Eye-bank preparation of endothelial tissue. Curr Opin Ophthalmol. 2014;25(4):319-324.

77. Lie JT, Birbal R, Ham L, van der Wees J, Melles GR. Donor tissue preparation for Descemet membrane endothelial keratoplasty. J Cataract Refract Surg. 2008;34(9):1578-1583.

78. Jardine GJ, Holiman JD, Galloway JD, Stoeger CG, Chamberlain WD. Eye bank-prepared femtosecond laser-assisted automated Descemet membrane endothelial grafts. Cornea. 2015;34(7):838-843. 
79. Ruzza A, Parekh M, Salvalaio G, et al. Bubble technique for Descemet membrane endothelial keratoplasty tissue preparation in an eye bank: air or liquid? Acta Ophthalmol. 2015;93(2):e129-e134.

80. Yoeruek E, Bayyoud T, Hofmann J, Szurman P, Bartz-Schmidt KU. Comparison of pneumatic dissection and forceps dissection in Descemet membrane endothelial keratoplasty: histological and ultrastructural findings. Cornea. 2012;31(8):920-925.

81. Vianna LM, Stoeger CG, Galloway JD, et al. Risk factors for eye bank preparation failure of Descemet membrane endothelial keratoplasty tissue. Am J Ophthalmol. 2015;159(5):829-834. e2.

82. Greiner MA, Rixen JJ, Wagoner MD, et al. Diabetes mellitus increases risk of unsuccessful graft preparation in Descemet membrane endothelial keratoplasty: a multicenter study. Cornea. 2014;33(11):1129-1133.

83. Heindl LM, Riss S, Bachmann BO, Laaser K, Kruse FE, Cursiefen C. Split cornea transplantation for 2 recipients: a new strategy to reduce corneal tissue cost and shortage. Ophthalmology. 2011;118(2):294-301.

84. Lam FC, Baydoun L, Dirisamer M, Lie J, Dapena I, Melles GR. Hemi-Descemet membrane endothelial keratoplasty transplantation: a potential method for increasing the pool of endothelial graft tissue JAMA Ophthalmol. 2014;132(12):1469-1473.

85. Palioura S, Colby K. Outcomes of Descemet stripping endothelial keratoplasty using eye bank-prepared preloaded grafts. Cornea. 2017;36(1):21-25.

86. Shah SU, Gritz DC. Application of the femtosecond laser LASIK microkeratome in eye banking. Curr Opin Ophthalmol. 2012;23(4) 257-263.

87. Juhasz T, Loesel FH, Kurtz RM, Horvath C, Bille JF, Mourou G. Corneal refractive surgery with femtosecond lasers. IEEE J Sel Top Quantum Electron. 1999;5(4):902-910.

88. Kezirian GM, Stonecipher KG. Comparison of the IntraLase femtosecond laser and mechanical keratomes for laser in situ keratomileusis. J Cataract Refract Surg. 2004;30(4):804-811.

89. Liu HH, Hu Y, Cui HP. Femtosecond laser in refractive and cataract surgeries. Int J Ophthalmol. 2015;8(2):419-426.

90. Bahar I, Kaiserman I, McAllum P, Rootman D. Femtosecond laserassisted penetrating keratoplasty: stability evaluation of different wound configurations. Cornea. 2008;27(2):209-211.

91. Jones YJ, Goins KM, Sutphin JE, Mullins R, Skeie JM. Comparison of the femtosecond laser (IntraLase) versus manual microkeratome (Moria ALTK) in dissection of the donor in endothelial keratoplasty: initial study in eye bank eyes. Cornea. 2008;27(1):88-93.

92. Vetter JM, Butsch C, Faust M, et al. Irregularity of the posterior corneal surface after curved interface femtosecond laser-assisted versus microkeratome-assisted descemet stripping automated endothelial keratoplasty. Cornea. 2013;32(2):118-124.

93. Tomida D, Yamaguchi T, Ogawa A, et al. Effects of corneal irregular astigmatism on visual acuity after conventional and femtosecond laserassisted Descemet's stripping automated endothelial keratoplasty. Jpn J Ophthalmol. 2015;59(4):216-222.

94. Trinh L, Saubaméa B, Auclin F, et al. Femtosecond and excimer laser-assisted endothelial keratoplasty (FELEK): a new technique of endothelial transplantation. J Fr Ophtalmol. 2014;37(3):211-219.

95. Bethke W. Can you afford to do femtosecond cataract? Rev Ophthalmol. 2011. Available from: https://www.reviewofophthalmology. com/article/can-you-afford-to-do-femtosecond-cataract. Accessed November 1, 2016.

96. Espana EM, Di Pascuale M, Grueterich M, Solomon A, Tseng SC. Keratolimbal allograft in corneal reconstruction. Eye (Lond). 2004;18(4):406-417.

97. Farid M, Lee N. Ocular surface reconstruction with keratolimbal allograft for the treatment of severe or recurrent symblepharon. Cornea. 2015;34(6):632-636.

98. Croasdale CR, Schwartz GS, Malling JV, Holland EJ. Keratolimbal allograft: recommendations for tissue procurement and preparation by eye banks, and standard surgical technique. Cornea. 1999;18(1):52-58.

99. Mason SL, Stewart RM, Sheridan CM, et al. Yield and viability of human limbal stem cells from fresh and stored tissue. Invest Ophthalmol Vis Sci. 2016;57(8):3708-3713.
100. Lawrence SD, Netland PA. Gamma-irradiated cornea allograft for glaucoma surgery. J Glaucoma. 2013;22(5):355-357.

101. Smith MF, Doyle JW, Ticrney JW Jr. A comparison of glaucoma drainage implant tube coverage. J Glaucoma. 2002;11(2):143-147.

102. Al-Torbak AA, Al-Shahwan S, Al-Jadaan I, Al-Hommadi A, Edward DP. Endophthalmitis associated with the Ahmed glaucoma valve implant. Br J Ophthalmol. 2005;89(4):454-458.

103. Ekici F, Moster MR, Cvintal V, Hu WD, Waisbourd M. Tube shunt coverage with gamma-irradiated cornea allograft (VisionGraft). Clin Ophthalmol. 2015;9:751-755.

104. Rumelt S, Rehany U. A donor corneal patch graft for an incompetent scleral flap following trabeculectomy. Ophthalmic Surg Lasers. 1996;27(10):878-880.

105. Nolan KW, Lucas J, Abbasian J. The use of irradiated corneal patch grafts in pediatric Ahmed drainage implant surgery. J AAPOS. 2015;19(5):445-449.

106. Daoud YJ, Smith R, Smith T, Akpek EK, Ward DE, Stark WJ. The intraoperative impression and postoperative outcomes of gammairradiated corneas in corneal and glaucoma patch surgery. Cornea. 2011;30(12):1387-1391.

107. Holiman J, LiY, Stoeger C, Huang D. The effects of a novel sterilization process on donor cornea clarity. 2014. Available from: http://visiongift. org/downloads/EBAA\%202014\%20Clarity\%20Final_Version\%202. pdf. Accessed November 1, 2016.

108. Gupta A, Jain S, Jain T, Gupta K. Awareness and perception regarding eye donation in students of a nursing college in Bangalore. Indian $J$ Community Med. 2009;34(2):122-125.

109. Tandon R, Verma K, Vanathi M, Pandey RM, Vajpayee RB. Factors affecting eye donation from postmortem cases in a tertiary care hospital. Cornea. 2004;23(6):597-601.

110. Dandona R, Dandona L, Naduvilath TJ, McCarty CA, Rao GN. Awareness of eye donation in an urban population in India. Aust NZ J Ophthalmol. 1999;27(3-4):166-169.

111. Siminoff LA, Arnold RM, Caplan AL, Virnig BA, Seltzer DL. Public policy governing organ and tissue procurement in the United States. Results from the National Organ and Tissue Procurement Study. Ann Intern Med. 1995;123(1):10-17.

112. Pineda R. Corneal transplantation in the developing world: lessons learned and meeting the challenge. Cornea. 2015;34(Suppl 10):S35-S40.

113. Rao GN, Gopinathan U. Eye banking: an introduction. Community Eye Health. 2009;22(71):46-47.

114. de Araujo AL, Gomes JÁ. Corneal stem cells and tissue engineering: current advances and future perspectives. World J Stem Cells. 2015;7(5):806-814.

115. Ramaesh K, Dhillon B. Ex vivo expansion of corneal limbal epithelial/stem cells for corneal surface reconstruction. Eur J Ophthalmol. 2003;13(6):515-524.

116. Mimura T, Yamagami S, Amano S. Corneal endothelial regeneration and tissue engineering. Prog Retin Eye Res. 2013;35:1-17.

117. Mimura T, Yamagami S, Yokoo S, et al. Cultured human corneal endothelial cell transplantation with a collagen sheet in a rabbit model. Invest Ophthalmol Vis Sci. 2004;45(9):2992-2997.

118. Honda N, Mimura T, Usui T, Amano S. Descemet stripping automated endothelial keratoplasty using cultured corneal endothelial cells in a rabbit model. Arch Ophthalmol. 2009;127(10):1321-1326.

119. Lai JY, Chen KH, Hsiue GH. Tissue-engineered human corneal endothelial cell sheet transplantation in a rabbit model using functional biomaterials. Transplantation. 2007;84(10):1222-1232.

120. Di lorio E, Ferrari S, Fasolo A, Böhm E, Ponzin D, Barbaro V. Techniques for culture and assessment of limbal stem cell grafts. Ocul Surf. 2010;8(3):146-153.

121. Fasolo A, Pedrotti E, Passilongo M, et al. Safety outcomes and longterm effectiveness of ex vivo autologous cultured limbal epithelial transplantation for limbal stem cell deficiency. Br J Ophthalmol. Epub 2016 Aug 19.

122. James SE, Rowe A, Ilari L, Daya S, Martin R. The potential for eye bank limbal rings to generate cultured corneal epithelial allografts. Cornea. 2001;20(5):488-494. 
123. Atala A, Kasper FK, Mikos AG. Engineering complex tissues. Sci Transl Med. 2012;4(160):160rv12.

124. Vázquez N, Chacón M, Meana Á, et al. Keratin-chitosan membranes as scaffold for tissue engineering of human cornea. Histol Histopathol. 2015;30(7):813-821.

125. Griffith M, Osborne R, Munger R, et al. Functional human corneal equivalents constructed from cell lines. Science. 1999;286(5447): 2169-2172.

126. Griffith M, Jackson WB, Lagali N, Merrett K, Li F, Fagerholm P. Artificial corneas: a regenerative medicine approach. Eye (Lond). 2009;23(10):1985-1989.

127. Guo X, Hutcheon AE, Melotti SA, Zieske JD, Trinkaus-Randall V, Ruberti JW. Morphologic characterization of organized extracellular matrix deposition by ascorbic acid-stimulated human corneal fibroblasts. Invest Ophthalmol Vis Sci. 2007;48(9):4050-4060.

128. Fagerholm P, Lagali NS, Merrett K, et al. A biosynthetic alternative to human donor tissue for inducing corneal regeneration: 24-month follow-up of a phase 1 clinical study. Sci Transl Med. 2010; 2(46):46ra61.

129. Mason C, Manzotti E. Regenerative medicine cell therapies: numbers of units manufactured and patients treated between 1988 and 2010. Regen Med. 2010;5(3):307-313.
130. Yam GH, Yusoff NZ, Goh TW, et al. Decellularization of human stromal refractive lenticules for corneal tissue engineering. Sci Rep. 2016;6:26339.

131. Sekundo W, Kunert KS, Blum M. Small incision corneal refractive surgery using the small incision lenticule extraction (SMILE) procedure for the correction of myopia and myopic astigmatism: results of a 6 month prospective study. Br J Ophthalmol. 2011;95(3): 335-339.

132. Sun L, Yao P, Li M, Shen Y, Zhao J, Zhou X. The safety and predictability of implanting autologous lenticule obtained by SMILE for hyperopia. J Refract Surg. 2015;31(6):374-379.

133. Ganesh S, Brar S. Femtosecond intrastromal lenticular implantation combined with accelerated collagen cross-linking for the treatment of keratoconus - initial clinical result in 6 eyes. Cornea. 2015; 34(10):1331-1339.

134. Angunawela RI, Riau AK, Chaurasia SS, Tan DT, Mehta JS. Refractive lenticule re-implantation after myopic ReLEx: a feasibility study of stromal restoration after refractive surgery in a rabbit model. Invest Ophthalmol Vis Sci. 2012;53(8):4975-4985.

135. Ganesh S, Brar S, Rao PA. Cryopreservation of extracted corneal lenticules after small incision lenticule extraction for potential use in human subjects. Cornea. 2014;33(12):1355-1362.
Journal of Biorepository Science for Applied Medicine

\section{Publish your work in this journal}

The Journal of Biorepository Science for Applied Medicine is an international, peerreviewed, open access journal that focuses on new developments and advances in the emerging and evolving field of biorepository science. This includes biospecimen procurement, processing, preservation, and banking for application to applied medicine. The Journal invites submission of manuscripts which address these aspects in addition to systems logic, clinical throughput and ethical issues pertaining to application of

\section{Dovepress}

biorepositories and their effects on clinical medicine. The journal is characterized by the rapid reporting of reviews, original research, methodologies, technologies and analytics in this subject area. The manuscript management system is completely online and includes a very quick and fair peer-review system, which is all easy to use. Visit http:/ www.dovepress.com/testimonials.php to read real quotes from published authors.

Submit your manuscript here: https://www.dovepress.com/journal-of-biorepository-science-for-applied-medicine-journal 